\title{
The Origins and Development of Judicial RECUSAl IN TEXAS
}

\author{
John C. Domino* \\ Sam Houston State University, USA
}

\begin{abstract}
In 21st century Texas, a judge's decision to recuse from a case is based on a complex set of norms, codes and procedures intended to promote impartiality. For most of the state's history, however, the sole ground for the removal of a judge from a case was not recusal for bias but disqualification based on rigid conditions set out in the Texas Constitution. This article examines the foundations and emergence of the modern concept of judicial recusal in Texas with the intent to illustrate a shift from rigid constitutional grounds to a more fluid approach based on judicial interpretation of a code of conduct. The author concludes that while Texas disqualification and recusal jurisprudence is conservative and restrained, it remains to be seen whether this restraint can continue unchanged in a post-Caperton era. The Caperton probability of bias standard has become part of the dialogue on recusal and disqualification in Texas, but Caperton-based challenges are unlikely to prevail in the near future because many members of the bench and bar share the belief that the state's judicial campaign contribution restrictions and recusal jurisprudence create a firewall against violations of the Due Process Clause. The risk, however, is that continued resistance to change may further erode public confidence in existing ethical safeguards and fall short of assuaging concerns that wealthy donors continue to exercise disproportionate influence on the judiciary.
\end{abstract}

\section{CONTENTS}

I. Constitutional and Common Law Origins ...................... 150

II. Emergence of Recusal for Bias in Texas .......................... 156

III. Disqualification, Recusal, and Judicial Politics ............. 162

IV. The Aftermath of Caperton in Texas.................................. 173

* Professor of Political Science and Legal Studies, Sam Houston State University. Email: jcd@shsu.edu 
Judicial recusal—a judge's withdrawal from a legal case because of personal bias or prejudice-is a mid-twentieth century development in Texas jurisprudence. In twenty-first century Texas, a judge's decision to recuse from a case is based on a complex set of norms, codes, and procedures intended to promote impartiality. For most of the state's history, however, the sole ground for the removal of a judge from a case was not recusal for bias but disqualification by reference to the conditions set out in the Texas Constitution. Although the two terms "disqualification" and "recusal" are often used interchangeably in Texas, the two concepts are differentiated because the legal authority and grounds for each are fundamentally different. If disqualified from a case on constitutional grounds, a judge does not have jurisdiction in the case and any ruling or decree made has no effect. ${ }^{1}$ Recusal from a case, on the other hand, occurs voluntarily if the judge's impartiality might reasonably be questioned. ${ }^{2}$ Refusal to recuse results in the transfer of the case to another court or assignment of another judge to the case. ${ }^{3}$ This article examines the foundations and the emergence of the modern concept of judicial recusal in Texas. It begins with an historical examination of disqualification rulings of the Texas Supreme Court and lower appellate courts in order to understand early foundational thinking about the circumstances under which a judge should not hear a case, but my primary interest here is the emergence of the body of rules and norms of behavior governing judicial recusal that arose in the late twentieth century. I hope to illustrate a shift from rigid constitutional grounds to a more fluid modern approach based on judicial interpretation of a code of conduct. Of course, the body of case law dealing with disqualification as well as recusal is substantial. A complete treatment is beyond the scope of a single article. The focus here will be on those rulings that have had a major precedential impact on the origins and development of the modern concept of recusal.

\section{Constitutional and Common Law Origins}

In nineteenth century Texas, the grounds for the removal of a judge from a case were pecuniary interest and consanguinity ${ }^{4}$ based on the Texas Constitution and the common law. The 1836 Constitution adopted by the Republic of Texas reflected the old English common law rule that the only basis for disqualification of a judge was direct pecuniary interest-that is,

\footnotetext{
Art. V, $\S 11$, of the Constitution of Texas.

Rule $18 \mathrm{~b}$ of the Tex. R. Civ. P.

See http://www.txcourts.gov/rules-forms/rules-standards.aspx.

The degree of affinity to parties in a lawsuit.
} 
financial interest in the outcome of the case. ${ }^{5}$ There is no evidence that judicial bias as a ground for mandatory or self-disqualification was adopted by any court or governing body at that time. The standard of the time followed Coke's axiom that "no man shall be a judge in his own case," 6 but rejected the idea that "bias" as a state of mind in contrast to pecuniary interest would disqualify a judge. Also controlling was Blackstone's view that a judge cannot be challenged or disqualified for the possibility of bias, only "interest." 7 The pecuniary interest standard was applied not only where the outcome of a case directly affected the judge's purse but also where a judge might collect a monetary fine that he had the power to impose or might benefit indirectly, for example, as a taxpayer. The problem of course then was that if a judge could potentially be disqualified on the grounds of being a taxpayer, many lawsuits could not be decided especially where there were few (or only one) judges in a sparsely populated area. Judicial disqualification in the Republic of Texas, however, was straightforward: judges were disqualified for financial interest but not for bias.

When Texas became a state in 1845, a new Constitution stated: "No judge shall sit in any case wherein he may be interested, or where either of the parties may be connected with him by affinity or consanguinity, within such degrees as may be prescribed by law, or where he shall have been counsel in the cause." ${ }^{8}$ This language also appeared in the Constitutions of 1861, 1866, and 1869 and is repeated in the present Constitution, which was adopted in 1876 . For more than a century, Texas courts held that the state's constitution provided the only necessary guidance for removing a judge from a case. The few appellate court opinions from this period show that any attempt to diverge from this rule and thus remove or disqualify a judge for any other reason was generally rejected; the language of the constitution on this matter was interpreted narrowly.

In Taylor $v$. Williams ${ }^{9}$ (1863), the Texas Supreme Court rejected efforts to remove a judge solely on the grounds that before becoming a sitting judge, he had been counsel in the case. The case arose when a disputed title to land was litigated before a judge who had appeared as counsel in similar cases dealing with the same title some years earlier. The Court recognized as settled under the common law that the slightest pecuniary interest in a cause would result in the judge's disqualification. However, nothing in the common law prevented a judge from hearing an appeal of a decision made while sitting as a trial judge or even serving as counsel. ${ }^{10}$ The judge's "professional connection" with the case, by virtue of the fact that he was "counsel in the cause," would only apply if the judge stood to gain financially. Taylor $v$ Williams is important because it rejected the attempt to "creat[e]

\footnotetext{
John P. Frank Disqualification of Judges, 56 YaLE L. J. 609-10 (1947).

6 See Sir Edward Coke, 1 Institutes of the Laws of England, 141a (19 ${ }^{\text {th }}$ ed. 1832).

William Blackstone, 3 Commentaries on the Laws of England 361.

Tex. Const. $\S 19$ (1845).

9 Taylor v. Williams, 26 Tex. 583 (1863).

10 Id. at 586.
} 
in the mind of the judge a bias, prejudice or partiality" as a ground for disqualification unrelated to that found in the constitution. ${ }^{11}$ In a classic statement of judicial restraint, the Texas Supreme Court wrote:

[W]e cannot undertake to say that his professional connection with a similar cause or one involving the same questions shall have that effect. If we depart from the plain language of the constitution [as grounds for disqualification], we shall be left without a rule for our guidance, and shall countenance a laxity of construction that may prove both dangerous and inconvenient." 12

In Slaven $v$. Wheeler (1882), ${ }^{13}$ the Texas Supreme Court ruled that Texas Constitution's provision that no judge shall sit in any case where he has been counsel included instances where the judge, acting as an attorney, gave advice about an issue in a dispute more than 10 years before it ripened into a lawsuit even though, as an attorney, he had not charged his client for the advice. The fact that he had once been consulted professionally as counsel barred him from sitting. The case originated when Elizabeth Slaven sued her husband for selling their property without her knowledge. During the trial, Mrs. Slaven sought to disqualify the presiding judge on the grounds that he had served as her counsel in the case 10 years earlier. On appeal, the Texas Supreme Court held that even though a decade had passed, the attorney-client relationship had continued because Mrs. Slaven had never terminated the relationship. For this reason, the judge was disqualified under the Texas Constitution and the judgment of the lower court was reversed. Justice Watts, writing for the court, ruled that the conclusion in Slaven was not at variance with Taylor $v$. Williams because in the latter case, the judge had not been professionally connected as counsel with the parties to the suit. ${ }^{14}$

The Texas Supreme Court even refused to disqualify a judge whose property had been stolen by the defendant tried before him. Ross Davis was indicted in 1875 for stealing 10 fence posts from a Judge Claiborne. The value of the fence posts was 2 dollars and 50 cents. Counsel for the defendant petitioned to disqualify Judge Claiborne from sitting in the case. Both parties agreed and the district attorney selected a local lawyer to be sworn in as a special judge. The trial proceeded and Davis was convicted. Davis appealed on the grounds that the special judge did not have authority to try the case. In Davis $v$. State (1876), ${ }^{15}$ the Texas Supreme Court ruled against Davis stating that the Texas Constitution prescribed for the selection of a special judge when a presiding judge was disqualified. ${ }^{16}$ However,

\footnotetext{
Id.

Id. at $586-87$.

358 Tex. 23 (1882).

Id. at 26.

544 Tex. 523 (1876).

16 Tex. Const. art. V $§ 11$ (1869).
} 
the Court concluded that it had not been necessary to disqualify Judge Claiborne. The judge might well have been angry with Davis for stealing his fence posts and have wanted to see him punished but was not constitutionally disqualified. It had not been shown that the judge was "interested" because he was neither a party nor liable to suffer a loss or gain a profit from the outcome. ${ }^{17}$ Accordingly, there was no need to appoint a special judge, the judgment against Davis was reversed and the case remanded. ${ }^{18}$

In Dailey v. State (1900), the Texas Supreme Court refused to disqualify a judge from hearing a case against a woman for keeping a "disorderly house," or brothel, even though the same judge belonged to an organization of local judges who met regularly to discuss closing down disorderly houses where prostitution and gaming took place. ${ }^{19}$

In 1918, the Court of Criminal Appeals relied on Davis when it ruled that evidence of a judge's prejudice against the accused did not constitute grounds for disqualification. In Berry $v$. State,${ }^{20}$ the court rejected an effort to remove a judge because "he ... had expressed his prejudice against the appellant" in an appeal from a conviction for the unlawful sale of liquor. The Court argued that the constitution alone set out the circumstances under which a judge should be disqualified. While some states had statutes requiring disqualification on the ground of prejudice, "[o]ur laws appear to proceed on the theory that prejudice against an accused does not disqualify the judge from trying the case..." 21 The logic was that any prejudice that the judge might have had toward the defendant was offset set by the fact that defendant's rights were still fully protected by the constitutional right to trial by an impartial jury and the right to appeal - a view that still influences judicial thinking on recusal to this day. The justices in Berry again rejected any considerations or evidence set out in a motion for disqualification beyond those specific and exclusive conditions covered by the constitutional provisions for removal.

That is not to say that early efforts to disqualify a judge were entirely without success. In Nalle v. City of Austin (1863), the Supreme Court ruled that a judge who presided in a lawsuit seeking an injunction to block an assessment of property taxes in the City of Austin was properly disqualified because the judge was a taxpayer in Austin and, therefore, had a direct pecuniary interest in the outcome of the case. ${ }^{22}$ This ruling deviated from cases where the common law rule of "necessity" required the judge to sit in a case involving a taxpayers suit even though the judge as a taxpayer would stand to benefit financial from the court's ruling. ${ }^{23}$ If a taxpayer judge could

17 Davis, 44 Tex. at 524.

18 Id. at 525.

19 Dailey v. State, 55 S.W. 821 (Tex. Crim. App. 1900).

20 Berry v. State, 203 S.W. 901, 902-03 (Tex. Crim. App. 1918).

21 Id. at 903.

22 Nalle v. City of Austin, 22 S.W. 668 (Tex. 1893).

23 BLACKSTONE supra note 8. See also Frederick Pollock, First Book of JurispruDENCE FOR STUdents of THE COMmon LaW 270 (6 $6^{\text {th }}$ ed. 1929). 
potentially be disqualified on the grounds of pecuniary interest, then many lawsuits could not be decided. The rule of necessity holds that when no substitute judge is available, the sitting judge should not decline to hear case. This rule was often invoked in rural areas where no substitute judge could be found. Even if the judge wished to be disqualified, appellate courts often ruled that the judge was required to sit in the case even in light of a potential bias or conflict of interest. ${ }^{24}$

The doctrines of consanguinity and affinity ${ }^{25}$ as they applied to disqualification refer to the degree of relationship between the judge and a party in a suit. The degree of consanguinity is based on the number of generations by which they are separated. Parents and children are related to each other in the first degree. A grandparent and grandchildren are related in the second degree. A husband and wife are (in most cases) related to each other not by consanguinity but by affinity in the first degree. So, for example, an attorney may not be involved in a case over which a judge is presiding if the attorney is related to the judge by one degree of consanguinity or affinity. ${ }^{26}$ In 1943, the Texas Supreme Court relied on cases from early in the state's history to disqualify a judge whose son was an attorney for the plaintiff in a worker's compensation suit over which the judge presided. ${ }^{27}$ The Court applied the Texas Constitution and a civil statute to disqualify the judge because the attorney-son met the definition of "party" under both. The court broadly construed the statute, reasoning that the word party was not restricted to litigants but all persons who were interested in the outcome of the case. ${ }^{28}$ Ellis built upon the 1909 case of Duncan $v$. Herder ${ }^{29}$ where the trial judge, the Hon. L.W. Moore, was disqualified by the reason of his relationship by affinity (within the third degree) to one of the parties in a complex probate case. Judge Moore's daughter-in law stood to gain as one of the heirs of the decedent, Mr. Lenert. So even though Mrs. Moore was not named as a party to the suit, she was a party within the meaning of term as used in the Constitution and statute.

In the 1920s and 1930s, no codes or rules were available to address ethical quandaries faced by sitting judges who were actively campaigning for office. Guidance on these matters would not exist until the first codes of judicial conduct were promulgated in the 1970s. In Love v. Wilcox (1930), a candidate for governor sought a writ of mandamus from the Texas $\mathrm{Su}$ preme Court to compel the State Democratic Committee to put his name on the ballot in the primary election. ${ }^{30}$ The party officials refused because the aspiring gubernatorial candidate had once supported Republicans and

24 The rule of necessity is said to have originated in England in the fifteenth century. The US Supreme Court recognized the rule in Evans v. Gore, 253 U.S. 245, 248 (1920).

25 Tex. Const. § 19 (1845).

26 See Tex. Gv. Code AnN. $\S 573.023573 .025$.

27 Postal Mut. Indemnity Co. v. Ellis,169 S.W.2d 482 (Tex. 1943).

28 Id. at 484-85.

29122 S.W. 904 (Tex. Civ. App. 1909).

30 Love v. Wilcox, 28 S.W.2d 515 (Tex. 1930). 
worked against Democrats. The sitting Chief Justice of the Texas Supreme Court believed that he was disqualified to hear the case on appeal because he was a candidate for the Democratic Party's nomination for Chief Justice that same year. He based his conclusion to self-disqualify not on Texas law but rather on a holding of the Supreme Court of Colorado that addressed the question of whether a judge who was a candidate in a primary election was qualified by his direct interest in the primary to participate in a case related to the primary. ${ }^{31}$ Neither Texas case law nor statute provided guidance, ${ }^{32}$ but the Supreme Court ruled that under the Texas Constitution the Chief Justice was not only qualified but duty bound to sit in the case. ${ }^{33}$ The majority argued that the Colorado decisions had no bearing on the matters of disqualification of a Texas judge because those cases applied statutes governing disqualification. In Texas, only the Constitution specified the grounds for disqualification. The Court held:

Under the Texas Constitution, it is the duty of the judge to sit save 'in any case wherein he may be interested, or where either of the parties may be connected with him by affinity, or consanguinity, within such a degree as may be prescribed by law, or when he shall have been counsel in the case. ${ }^{34}$

For 40 more years, the Texas courts continued to maintain this view. In 1972, rejecting the entire notion of recusal for bias, the Texas Court of Appeals ruled in Maxey $v$. Citizens National Bank of Lubbock ${ }^{35}$ that

[w] hile delicate discretion might indicate a judge's withdrawal from a case in a contentious situation, there is no compulsion to step aside when the judge is not legally disqualified; indeed, unless legally disqualified, it is the duty of the judge to preside. [...] [...] Because the constitutional and statutory grounds are inclusive and exclusive, mere prejudice and bias are excluded as a disabling factor. ${ }^{36}$

Today, it would be hard to imagine a judge admitting that "mere prejudice and bias" are not grounds to consider disqualification. ${ }^{37}$

\footnotetext{
$I d$. at 517.

Id. at 518 .

Id.

Id.

489 S.W.2d 697, 702 (Tex. Civ. App. - Amarillo, 1972).

Id.

37 In 1973, Williams v. State, 492 S.W.2d 522 (Tex. Crim. App. 1973), the Court of Criminal Appeals reiterated the century-old rule that "Article V, Section 11, of the Constitution of Texas, provides for the circumstances under which a judge is disqualified ... The constitutional grounds of disqualification are exclusive; that is, they specify all the circumstances that forbid a judge to sit."
} 


\section{Emergence of Recusal for Bias in Texas}

In 1974, the Supreme Court of Texas acted upon the recommendation of the American Bar Association and adopted the ABA Code of Judicial Conduct, Canon 3C (1), promulgated in 1972. ${ }^{38}$ The idea of a code of ethics for judges was not a new idea. The "Canons of Judicial Ethics" had been in existence since 1924 when an ABA committee led by the Chief Justice of the United States, William Howard Taft, drafted them as ethical guidance for judges. The Canons were eventually replaced by the 1972 ABA Code. In 1974, shortly before the ABA Code went into effect in Texas, a motion was filed to disqualify a trial judge in a case involving the termination of a parent-child relationship. The trial judge, seeing evidence of child abuse, overruled the district attorney's office and ordered the investigation of the parent for possible criminal prosecution. The judge then went on to discuss the case with the media, making statements to reporters about facts that were not reflected by evidence in the case, including the allegation that the child had been tortured..$^{39}$ Numerous newspaper articles reported the judge's allegations, which indicated animus toward the parents. The mother filed to disqualify the judge on two grounds: (1) under Art. V., Section 11 of the Texas Constitution, the judge's statements "put himself in the position of counsel..." and (2) the judge had a personal bias that precluded a fair trial under the 1974 Judicial Code. The trial judge refused to disqualify himself. However, on appeal in Shapley $v$. Texas Dep't of Human Resources, the Court of Appeals ruled that the trial judge acted unethically by ignoring the Code of Judicial Conduct by publicly stating his bias and prejudice to the media during an ongoing trial. Following the judge's public statements, the parties in the case no longer believed that they would be treated fairly and impartially. ${ }^{40}$ The Court of Appeals wrote:

38 ABA Code of Judicial Conduct, Canon 3C (1) states that: A Judge should disqualify himself in a proceeding in which his or her impartiality might reasonably be questioned, including, but not limited to, instances where

(a) he or she has a personal bias at prejudice concerning a party or personal knowledge of disputed evidentiary facts concerning the proceeding;

(b) he or she served as a lawyer in the matter of controversy or as a lawyer with whom he or she previously practiced law served during such association as a lawyer concerning the matter, or the judge or such lawyer has been a material witness concerning it... (c) he or she knows that he or she, individually or as a fiduciary, or his or her spouse or minor child residing in his or her household, has a financial interest in the subject matter controversy or in a party to title proceeding, or any other interest that could be substantially affected by the outcome of the proceeding...

39 Shapley v. Texas Dep't of Human Resources, 581 S.W.2d 250 (Tex. Civ. App. - El Paso 1979).

40 Id. at 253. 
Now under the Code, the subject of disqualification has been broadened and the direction has been made that a judge should disqualify himself in a proceeding in which his impartiality might reasonably be questioned. ${ }^{41}$

Shapley represents a shift of great magnitude. For the first time, a Texas appellate court recognized (1) bias as a grounds for judicial disqualification and (2) that the Code expanded the grounds for disqualification beyond the constitutional grounds. Prior to the effective date of the Code, the grounds for disqualification enumerated by the Constitution were held to be both inclusive and exclusive. Prior to Shapley mere bias and prejudice were not disabling factors.

The Court of Appeals further explained that the ethical problem did not arise from the comments made by the trial judge in court but those made to the media outside of the courtroom in the course of a trial that was still ongoing. This was contrary to Canon $3 \mathrm{~A}(6)$, which provided that a judge should abstain from making public comments about a pending or an impending proceeding. ${ }^{42}$ However, under the old "independent grounds" standard, the judge would not have needed to recuse himself after he reacted publicly to the evidence during trial because he developed this bias from information gleaned during the trial. ${ }^{43}$ Lastly, the Court of Appeals pointed out that the trial judge in refusing to disqualify himself had ignored Art. 200a, sec. 6, Tex. Rev. Civ. Stat. Ann. (Supp. 1978-1979), which outlined the procedure for the referral of a motion for disqualification to another judge or court. ${ }^{44}$ As the mother did not raise this latter point, the Court addressed the merits of her challenge to the district court's parental termination judgment. Prior to Art. 200a, sec. 6, if a judge's impartiality was challenged, he or she made the call. If it was an incorrect decision, then it could be reversed on appeal. Thus, Shapley is a transitional case bridging the old and new standard for disqualification. It was also the first substantive and authoritative interpretation of the new norms for recusal by a Texas court. The concept of recusal for bias had now emerged 143 years after the founding of the Texas Republic.

In 1979-the same year as the Shapley ruling-the Texas Supreme Court handed down another landmark opinion on recusal. In McLeod v.

${ }^{41}$ Id. The Court of Appeals cites the 1975 case of Chilicote Land Co. v. Houston Citizens Bank \& Trust Co., 525 S.W. 2d 941 (Tex. Civ. App. - El Paso 1975), which simply recognizes without amplification that the 1974 adoption of the Code of Judicial Conduct Canon 3.c. broadened the grounds for disqualification beyond that set forth in the Texas Constitution.

42 Canon 3A(6) states: A judge should abstain from public comment about a pending or an impending proceeding in any court and should require similar abstention on the part of court personnel subject to his or her direction and control. This subsection does not prohibit judges from making public statements in the course of their official duties or from explaining for public information the procedures of the court.

43 Id. at 253.

44 Id. 
Harris, ${ }^{45}$ the Court ruled that motions to recuse must be referred to a presiding judge for assignment to another judge for hearing. In a divorce proceeding, Mr. McLeod filed a recusal motion against Judge Harris because of a close personal relationship between Mrs. McLeod and the judge and because of political differences between Mr. McLeod and the judge. The Court pointed out that the motion to recuse did not in itself disqualify but required that another judge be assigned to rule on the merits of the motion. The substantive grounds for disqualification, the Court reiterated, were contained in the Texas Constitution. ${ }^{46} \mathrm{McLeod}$ represented another major change in the Supreme Court's recusal jurisprudence. Lower court judges understood that they were bound by the decision but expressed frustration and balked at McLeod-arguing that trials would now be encumbered by the ripple effect phenomenon caused by the filing of multiple recusal motions.

In Robb v. Robb (1980), ${ }^{47}$ the wife in a divorce case filed a recusal motion alleging that the judge was biased in favor of the husband's attorneys because they had made contributions to the judge's campaign. The Court of Appeals observed that McLeod had placed no guidelines or limits on the form, time, or contents of motions to recuse. The one-sentence provision (Section 6 of Article 200a) of the statute applied by the Court in McLeod was all there was concerning recusal. "Therein lies our problem with this case." 48 The Court of Appeals stated that "we are bound by that decision and follow it ... but are not precluded from questioning its soundness, for the constitution cannot be amended by judicial fiat." 49

In 1981, the Texas Supreme Court adopted Rule 18a, thus giving more specificity to recusal and disqualification rules by adding procedures and time limits. ${ }^{50}$ The rule was amended a number of times, first in 1984 clarifying that it applied only to trial judges and not appellate courts of civil jurisdiction. A 1986 amendment to 18 a excluded the Texas Court of Criminal Appeals. ${ }^{51}$ So three rules now established the terms guiding the disqualification of judges: (1) Rule 18a, (2) Article 200a, and (3) Canon 3C of the Code of Judicial Conduct. The century and a half old axiom that the grounds for disqualification found in the constitution were to be regarded as "inclusive and exclusive" had been augmented by a broad category of grounds for recusal. In 1985, the legislature repealed Article 200a, leaving only Rule $18 \mathrm{a}$ and the Code of Judicial Conduct. However, in 1988, the legislature adopted Rule $18 \mathrm{~b}$, which provided specific grounds for disqualification and recusal. Judges were now guided by ethical canons, statutory requirements,

$45 \quad 582$ S.W.2d 772 (Tex. 1979).

46 Id. at 775 .

47 Robb v. Robb, 605 S.W.2d 390(Tex. Civ. App.— El Paso 1980).

48 Id. at 390.

49 Id.

50 18a (as a rule of civil procedure) became effective in 1982 and was rewritten in 2011. See Tex. R. Civ. P. 18a (Recusal and Disqualification of Judges).

51 See Tex.R. App. P. 16 (Disqualification or Recusal of Appellate Judges). 
and rules articulated by the courts responding to motions for recusal and disqualification based on "any disability of the judge." Yet many trial as well as appellate judges still fought against the concept of recusal, maintaining that recusal and disqualification are two different concepts and that the only legitimate grounds for disqualification were those found in the Constitution.

One of the most important and frequently cited ${ }^{52}$ Supreme Court precedents in recusal jurisprudence is In Re Union Pacific Resources Co. ${ }^{53}$ handed down in 1998. The case originated when plaintiffs sued the Union Pacific Resources Company for personal injury damages. They moved to recuse the trial judge (Judge Bennett) on the grounds that the attorney for the law firm representing Union Pacific was also currently representing Judge Bennett in an ongoing recusal hearing. Plaintiffs alleged that Judge Bennett's impartiality might reasonably be questioned because of the attorney-client relationship. Judge Bennett refused to recuse himself and pursuant to Texas Rule of Civil Procedure 18a(d) forwarded the motion to recuse to the presiding judge for the administrative district. The presiding judge appointed Judge Blackmon, a district judge, who held a hearing at which Judge Bennett testified. Judge Blackmon granted the recusal motion, but then after Judge Bennett wrote to Judge Blackmon requesting a rehearing on the recusal matter, Judge Blackmon reversed himself. Now frustrated, the plaintiffs suing Union Pacific sought a writ of mandamus from the Court of Appeals to reverse Judge Blackmon. ${ }^{54}$

Union Pacific raised a unique question: is recusal required of a trial judge when an attorney for a party (representing Union Pacific) in the judge's court concurrently represents the same judge in recusal proceedings? Plaintiffs argued that the active participation by a challenged judge in a recusal proceeding must lead to the judge's recusal. ${ }^{55}$ The Court of Appeals conditionally issued a writ of mandamus ordering the trial court to vacate its order denying the recusal motion. ${ }^{56}$

In recusal jurisprudence, mandamus is used in extraordinary circumstances to require a trial court to act in a particular way, in this case to compel a judge to recuse. To seek a writ of mandamus is not to seek an appeal but to initiate an original proceeding against a judge or court demonstrating that there is a clear abuse of discretion on the part of the judge for which there is no legal or constitutional remedy. ${ }^{57}$ The party must show that

52 Union Pacific is cited by 3 subsequent Texas Supreme Court opinions, 2 Texas Court Criminal of Appeals opinions, and 118 Court of Appeals opinions (Westlaw and LexisNexis searches, 4/15/15).

53969 S.W.2d 427 (Tex. 1998).

54 Monroe v. Blackmon, 946 S.W. 2d 533 (Tex. App.—Corpus Christi 1997).

55 Id. at 538.

56 Id.

57 Walker v. Packer, 827 S.W.2d 833, 840 (Tex. 1992). 
there is real danger of permanently losing substantive rights. ${ }^{58}$ Thus, a court will not issue a writ of mandamus absent "compelling circumstances." 59

On appeal, the Texas Supreme Court reversed the Court of Appeals' decision to issue the writ of mandamus because the plaintiffs had "adequate remedy by appeal" and the appeals court abused its discretion by issuing the writ. Chief Justice Phillips set out the following rule: judges may be removed from a case because they are disqualified under the Constitution ${ }^{60}$ or by statute ${ }^{61}$ or are recused by rules promulgated by the Texas Supreme Court. ${ }^{62}$ The legal grounds for each type removal are fundamentally different, he argued. When a judge refuses to recuse himself or herself contrary to the Constitution, any orders or judgments issued by a judge in that instant are void and without effect. Similarly, any orders or ruling made by a judge who is disqualified under statute are void. ${ }^{63}$ In both instances, a writ of mandamus is available to the parties to compel the judges' disqualification without showing that the challenger lacks an adequate remedy by appeal. However, in Union Pacific, the erroneous denial of a recusal motion by the presiding judge did not nullify the judge's actions. A judgment rendered in such circumstances may of course be reversed on appeal but not by writ of mandamus. If the appellate court determines that the judge presiding over the recusal hearing abused his or her discretion in denying the motion and the trial judge should have recused, then the appellate court can reverse the trial court's judgment and remand for a new trial with a new judge. In extraordinary instances, where, for example, a judge flagrantly refuses to follow procedural rules governing recusal, then the writ of mandamus is appropriate. ${ }^{64}$

Justice Hecht, concurring in Union Pacific, made three very important points: "[j]udges should not inject themselves too far into recusal hearings," "a hearing on a motion to recuse is not a trial of the judge's character and should not be treated as such," and it may be necessary for the judge to testify about the facts contained in the motion to recuse but should not testify on the issue of perceived impartiality or bias. ${ }^{65}$ Judge Bennett had called himself as a witness, presented evidence, and given oral argument. ${ }^{66} \mathrm{Hecht}$ concluded: "The less involved a judge is involved in recusal proceedings, voluntarily or involuntarily, the better." 67

Thus while in early Texas legal history, courts had resisted the urge to look inside the judge's mind for signs of favoritism or signs of bias toward

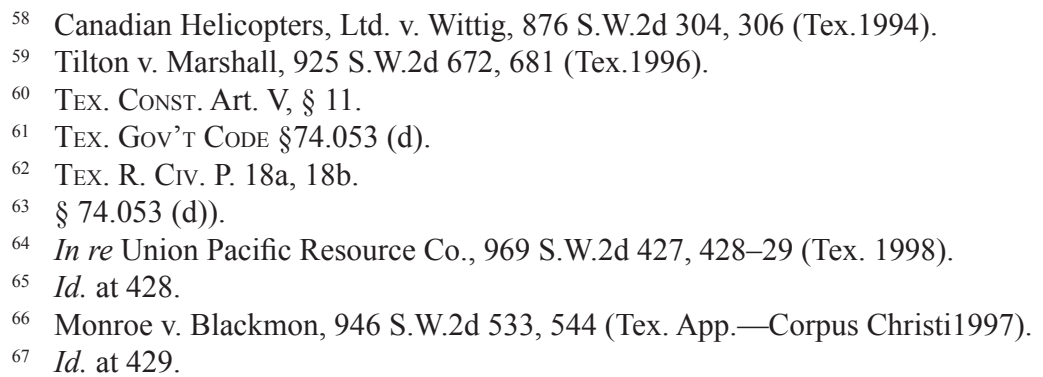


litigants or counsel, by the 1980 s, the courts were prepared to go there. Would demonstrating favoritism or demonstrating a clear bias toward litigants or counsel be grounds for recusal? According to precedent, behavior that prompts the motion for recusal must be based on an "extrajudicial source." ${ }^{68}$ This is a somewhat nebulous concept. Behavior or statements on the part of the judge made outside the courtroom prior to a case or made in another case that shows that the judge is prejudiced or biased against one party in a pendant case might be grounds. The motion would need to show that the judge developed an opinion about the case or parties based on information other than that which the judge learned from participation in the case. "[T]o require recusal, a judge's bias must be extrajudicial and not based on in-court rulings..." ${ }^{69}$ Rulings or decrees by judges based on the information gleaned during the course of a proceeding are not grounds for removal. ${ }^{70}$ This is supported by federal precedent as well. Responding to the question of whether during the course of a proceeding the trial judge's "impatience, disregard for the defense and animosity" are grounds for recusal, the US Supreme Court ruled in Liteky v. U.S. that "judicial rulings alone almost never constitute valid basis for a bias or partiality motion ..."71 The Liteky rule was adopted by the Texas Court of Appeals in In Re M.C.M., ${ }^{72}$ where the Court ruled that recusal is warranted only if it is shown that the bias arises from "an extrajudicial source and not from actions during the pendency of the trial court proceedings, unless these actions during proceedings indicate a high degree of favoritism or antagonism..." 73 This sounds very straightforward but is far from being so. In Norton v. State, ${ }^{74}$ for instance, a trial judge made a statement in a fit of pique prior to going to trial, proclaiming that regardless of the State's argument or the jury's verdict, he would make his own decision regarding the defendant's punishment for credit card fraud..$^{75}$ When the judge was asked if he would accept a plea bargain of deferred adjudication, he replied: "No, and if the jury gives her probation I'll give her jail time." 76 The Court of Appeals reversed the defendant's conviction and ordered a new trial stating that the trial judge's statement was an "arbitrary refusal to consider the entire range of punishment and constituted a denial of due process." 77 Thus, in Norton, the court ruled that the judge should have recused not because of extrajudicial information

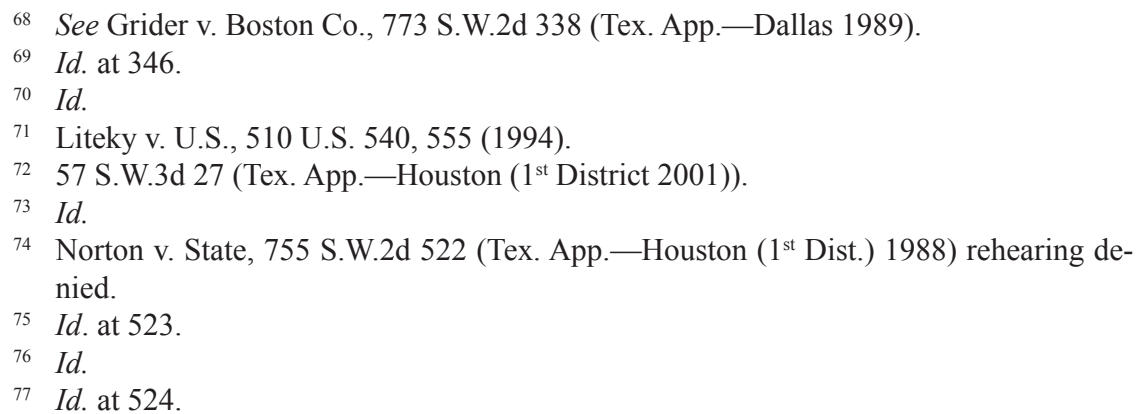


that caused him to be biased against the defendant but because of the statement he made in anger even before the case went to trial. ${ }^{78}$

Whether a judge should explain the reasoning underlying a decision to recuse or disqualify himself or herself has generated some debate. In Thomas $v$. Walker (1993), the Court of Appeals explained that the "mental processes rule" protects judges from being subjected to explaining their reasoning underlying a recusal decision except in the "most extreme and extraordinary circumstances." "[A] [A inquiry into his or her mental processes [however messy] in arriving at his decision would be improper and would threaten the foundation of an honorable and independent judiciary." 80

\section{Disqualification, Recusal, and Judicial Politics}

Matters concerning the doctrinal subtleties, states of mind of judges, and norms inherent in recusal jurisprudence have paled in comparison to the issue of whether judges should be recused or disqualified when they have received campaign contributions from law firms, corporations, and political action committees that have a direct stake not merely in the political composition of the court but in the voting patterns of individual judges and justices in a specific policy areas. ${ }^{81}$ In August 2002, just prior to the November general election, the Texas Supreme Court amended provisions of the Texas Code of Judicial Conduct that regulate the campaign conduct of state judicial candidates. ${ }^{82}$ In doing so, it struck from the Code a provision that prohibited a candidate from making statements of opinion on issues that might come before the court to which the candidate sought election. This change followed Republican Party of Minnesota $v$. White $e^{83}$ in which the US Supreme Court declared that judicial candidates have a First Amendment right to announce their views on legal disputes or issues that might come before them as a judge. White was at first interpreted to mean that every code of conduct

78 Id.

79 Thomas v. Walker, 860 S.W.2d 579 (Tex. App.-Waco 1993).

80 Tate v. State, 834 S.W.2d 566, 569. (Tex. App.-Houston (1 $1^{\text {st }}$ Dist.) 1992).

81 Much has been written on the invidious relationship between campaign money and judicial independence. See the ongoing work of Anthony Champagne and Kyle Cheek, specifically Anthony Champagne \& Kyle Cheek, The Cycle of Judicial Elections: Texas as a Case Study, 29 Fordham Urban L. J. 907 (2002) and Kyle Cheek \& Anthony Champagne, Judicial Politics in Texas: Partisanship, Money, and Politics in State Courts (2005).

82 Approval of Amendments to the Texas Code of Judicial Conduct, Misc. Docket No. 02-9167 (Tex. Aug. 22, 2002) [hereinafter Texas Amendments] (amending Canons 3, 5 and 6 of the Texas Code).

83536 U.S. 765 (2002). 
regulating judicial speech must be subject to strict scrutiny and that state codes of judicial conduct would have to be rewritten so that they did not limit the political speech of judges. Of course making political statements is not the same as making promises that would lead to the reasonable person doubting the judge's impartiality. So in most instances, campaign statements on "disputed legal issues" by judicial candidates cannot be grounds for disqualification. White allows candidates for judicial office to raise as issues in their campaigns matters that may come before them if they are elected. This puts judges in a tough spot if, on one hand, they wish to maintain their impartiality or independence but, on the other, are engaged in a competitive elections. The Texas Supreme Court also narrowed a blanket prohibition on any candidate making pledges or promises during a campaign but included the following language: "a statement made during a campaign for judicial office ... may cause a judge's impartiality to be reasonably questioned in the context of a particular case and may result in recusal." 84

Following Republican Party $v$. White, the Texas appellate courts have handed down only two influential rulings having an impact on motions to recuse or disqualify judges who are engaged in political activity: Ex Parte Ellis ${ }^{85}$ and In re Hecht.$^{86}$ Ex parte Ellis ${ }^{87}$ originated when the State of Texas $^{88}$ filed a motion to recuse Court of Appeals (Third District, Austin) Justice Alan Waldrop from an ongoing criminal case. Defendants James Ellis and John Colyandro were charged with election code violations and money laundering. Both men worked for former US House majority Leader Tom DeLay, who ultimately would be convicted for federal conspiracy and money laundering charges. The recusal motion stated that while Waldrop was engaged in private practice before his 2005 appointment ${ }^{89}$ to the Court of Appeals, he served as counsel for a Republican organization called Texans for Lawsuit Reform (TLR). TLR's members regularly attended campaign strategy sessions with Colyandro. As counsel, Waldrop filed a number of

${ }^{84}$ Canon 5 prohibits a judge from engaging in an inappropriate political activity, such as making pledges or promises of conduct in office regarding pending or impending cases, specific classes of cases, specific classes of litigants, or specific propositions of law that would suggest to a reasonable person that the judge is predisposed to a probable decision in cases within the scope of the pledge... It also states that a judge or judicial candidate may attend political events and express his or her views on political matters in accord with this Canon and Canon $3 \mathrm{~B}(10)$; however "A statement made during a campaign for judicial office, whether or not prohibited by this Canon may cause a judge's impartiality to be reasonably questioned in the context of a particular case and may result in recusal." http://www.scjc.state.tx.us/

$85 \quad 275$ S.W.3d 109 (2008).

$86 \quad 213$ S.W.3d 547 (2006).

87 Ex parte Ellis; Ex parte Colyandro, 275 S.W.2d 109 (2009).

88 Travis County District Attorney Ronny Earle and Assistant District Attorney Holly Taylor filed the motions.

89 Justice Waldrop was appointed by Governor Rick Perry in 2005, won election in 2006, and resigned in 2010, two years before his term ended. 
pleadings in a civil case on TLR's behalf that involved legal issues similar to those raised in the Ellis/Colyandro criminal appeal that was currently before Justice Waldrop. ${ }^{90}$ The State's motion to recuse was based entirely on statements Waldrop made as an attorney in a civil suit and not on anything he said or wrote as a justice on the Court of Appeals. ${ }^{91}$ The plaintiffs (Democrats) in this earlier civil suit attempted to serve TLR with a subpoena seeking documents and records of TLR's communications with another group called Texans for a Republican Majority Political Action Committee (TRMPAC). Jim Ellis and John Colyandro were affiliated with TRMPAC. ${ }^{92}$ In his successful effort to fight the subpoena Waldrop, then serving as TLR's attorney, signed and filed pleadings on behalf of TLR referring to the case as a "politically motivated lawsuit" without merit and simply a means of harassing a political opponent. The State in its petition for Justice Waldrop's recusal argued that although the plaintiffs in the civil suit are not parties in the current case, Justice Waldrop should recuse from this case because his "politically motivated" comment as a private attorney clearly demonstrated biases about the nature of the charges being challenged before the Court of Appeals. ${ }^{93}$ After the State filed the motion to recuse, Justice Waldrop certified the matter to the full Court.

The Court of Appeals ruled 3-2 against the motion to recuse, arguing that when the basis for a recusal motion originates from events occurring from a judge's legal career before appointment to the bench, it must be recognized that when representing clients lawyers are required to express the beliefs of their clients and advocate their clients' interests. Therefore, statements made by a lawyer representing a client, without more, "can only rarely serve as legitimate reasons for excluding a judge from fulfilling his or her sworn duties." 94 Were the rule otherwise, then judges would be recused from all cases that present issues similar to the ones that they confronted in their prior careers as advocates. Paradoxically, such a rule would lead to the view that the more expansive a judge's prior law practice are and experience, the more limited his or her judicial role could be.

Justice Patterson, dissenting in Ex Parte Ellis, concluded that Justice Waldrop should have recused himself from further participation in any appeals by Ellis and Colyandro. Waldrop's conduct as a private litigator in related civil proceedings was more than sufficient to cast reasonable doubt on his impartiality in these appeals. He represented a group that worked with, was ideologically aligned with, and had similar goals as the two de-

$90 \quad$ Ex parte Ellis; Ex parte Colyandro, 275 S.W.2d 109 (2009) 113.

91 The State cited Tex. R. Civ. P 18b(2)(a), which states that a "judge shall recuse himself in any proceeding in which... his impartiality might reasonably be questioned," and $18 \mathrm{~b}(2)(\mathrm{b})$, which provides that a "judge shall recuse himself in any proceeding in which ... he has a personal bias or prejudice concerning the subject matter..."

92 Id.

93 Id. at 114.

94 Id. at 113. 
fendants..$^{95}$ The rules and judicial canons not only require judges act with absolute impartiality but that judges also ... "appear to be impartial, so as to not call into question the fairness or integrity of the court ..." Rules of recusal do not require legal proof that a judge engaged in biased or prejudicial conduct but do require the judge to recuse himself if "his impartiality might reasonably be questioned." ${ }^{6}$

The second post-Republican Party $v$. White case, In re Hecht, ${ }^{97} \mathrm{did}$ not involve a motion for recusal but a possible violation of the Code of Judicial Conduct. This was a highly visible case that shed light on the extent to which judges are able to campaign for other candidates without needing to worry about disqualification or recusal. The case originated 2005 when the State Commission on Judicial Conduct voted to initiate an investigation of long-serving Texas Supreme Justice Nathan Hecht based on his statements appearing in the New York Times and Texas Lawyer endorsing his friend Harriet Miers. Ms. Miers was nominated by President George W. Bush in 2005 to replace retiring Associate Justice Sandra Day O'Connor. The Commission informed Hecht of the investigation and requested that he answer a questionnaire about the articles and his actions preceding and during Miers' nomination to the US Supreme Court. Hecht answered the questions and voluntarily appeared at a hearing before eight members of the commission. The commission determined that Justice Hecht violated Canons 2B and 5(2) of the Texas Code of Judicial Conduct and issued a public admonition. Canon $2 \mathrm{~B}$ states that "A judge shall not lend the prestige of judicial office to advance the private interests of the judge or others ...," and Canon 5 (2) states that "A judge shall not authorize the public use of his or her name endorsing another candidate for any public office ..." At the time, Hecht was up for reelection to the Texas Supreme Court. Hecht made clear through his comments about Miers his views on a range of "culture wars" issues that would likely come before the Texas Supreme Court.

Hecht and Miers had known each other for 35 years and had practiced in the same law firm from 1976 to 1981. Miers had served as White House Counsel to President Bush. Hecht was also a longtime friend of Karl Rove, White House Deputy Chief of Staff. Rove asked Hecht to speak to Dr. James Dobson, the founder of Focus on the Family (a conservative religious organization) about Miers' faith, which Rove believed would appeal to an important segment of Bush supporters. Rove also asked Hecht to speak to the media about Miers' qualifications and accomplishments. The Commission believed that Hecht leveraged his reputation to help Miers win confirmation. Hecht, a sitting justice, had acted as a one-man campaign team for Miers, ${ }^{99}$ echoing her views on abortion and other social issues. Of course,

95 Id. at $136-37$.

96 Id. citing Gammage J. in Rogers v. Bradley, 909 S.W.2d 872. (Tex. 1995).

97213 S.W.3d 547 (2006).

98 Id. at 551-52.

$99 \quad I d$. at 554-55. 
Miers ultimately withdrew her name from consideration after it was clear that she would not make it past the Senate Judiciary Committee. ${ }^{100}$

After the Commission's public admonition, Hecht requested a de novo review of the decision. ${ }^{101}$ Texas Supreme Court Chief Justice Wallace Jefferson then appointed (by random selection) members of a Special Court of Review ${ }^{102}$ to review the commissions' decision. The Special Court conducted an evidentiary hearing calling Justice Hecht as the sole witness. Expert testimony was given by a range of experts, including former Chief Justice Tom Phillips, a well-respected expert on judicial ethics. The Special Court then overturned the commission's ruling. ${ }^{103}$

Writing for the majority, Justice Kerry P. Fitzgerald recognized that contrary to the commission's allegation, there was no evidence that Hecht "authorized" the public use of his name in endorsing Miers. Canon 8A encourages "reasonable and reasoned application of the text," so Justice Fitzgerald decided to construe the language in Canon 5(2) in the same manner-narrowly. Thus, Hecht may have "supported" Miers but he did not "authorize" his name to be used in support of her nomination. In its 1990 amendments, the Texas Supreme Court did not reinstate the 1974 "endorsement" prohibition. It deleted "endorse" and added "authorize." 104 So if Hecht wasn't authorizing the use of his name and position to support Miers, what then constitutes an authorization? When does a judge cross the line? In Public Admonition of Justice of the Peace Torres, the Commission on Judicial Conduct stated that a judge is in violation of the Canon 5(2) if he or she gives the candidate express permission to include said judge's name on a publicly distributed list of persons endorsing the candidate. ${ }^{105}$ Justice Hecht may have anticipated his name being used as the person who gave the interview if the media chose to identify him, but he did not authorize the media to use his name to publicly endorse Miers. In his testimony, Hecht admitted that "of course you're endorsing in the sense that you're supportive, but that's not what the canon means." 106 The intent was to limit the roles that judges would have in lower court elections. The Special Court concluded that Hecht's statements did not constitute an "endorsement" and

\footnotetext{
100 https://www.congress.gov/nomination/109th-congress/978.

101 Id.

102 Tex. Gov't Code Ann. § 33.034(c) (Vernon 2004).

103213 S.W.3d 547, 580.

104 Id. at 562-565.

105 Public Admonition of Justice of the Peace Torres, No. 00-0689 - JP (Comm'n Jud. Conduct, Aug. 16, 2000).

106 Hecht testified that he was present on the Supreme Court when the canons were amended in 1990: "[T]here was not the slightest thought that it would ever apply to comments made in respect to a nomination to the United States Supreme Court. That was not a concern, it never crossed anybody's mind, and it hasn't since until this case," 213 S.W.3d 547, 560-563.
} 
that judges are permitted to speak out on political matters without fear of disqualification, the need to recuse, or a violation of ethics. ${ }^{107}$

The Commission's second charge alleged that Hecht violated the prestige of his public office to advance the interests of his friend Harriet Miers in violation of Canon $2 \mathrm{~B}$, which provides that " $\mathrm{A}$ judge shall not lend the prestige of judicial office to advance the private interests of the judge or others ..."108 The Special Court disagreed with the commission's position that Miers was pursuing private interests as opposed to public service. A judge campaigning or supporting another candidate is engaged in political speech and is not advancing a private interest even though a judge receives compensation, and in the case of Miers, employment for life. ${ }^{109}$

Justice Ann Crawford McClure, the third member of the special court, believed that Hecht had violated both Canon 5(2) and Canon 2B. She believed that the record showed that Hecht gave his endorsement to Miers. He voluntarily participated in rallying support for Miers's nomination and in mounting a "campaign" to convince religious conservatives that she was the real deal. So he endorsed her and voluntarily authorized the public use of his name and office and the prestige of his office to support his friend, both of which amounted to willful and persistent violations of Article V, Section 1-a(6) of the Texas Constitution and Canon 2B of the Texas Code of Judicial Conduct. However, Justice McClure argued that the Canons intrude into a judge's private life and are unconstitutional, ${ }^{110}$ contrary to Republican Party of Minnesota $v$. White. ${ }^{111}$ In sum, no solid legal grounds for disqualification or motions to recuse exist when a judge or judicial candidate campaigns or makes a statement of support for another candidate even when doing so has the effect of revealing his or her own political philosophy, views of specific issues, or assessments of the motivations of parties who bring a suit. Long-standing precedent extending back to the nineteenth century recognizes that judges are obligated to decide matters before them and not recuse themselves unnecessarily even in cases in which they might prefer not to participate because of embarrassing criticism or mere allegations of bias. ${ }^{112}$ The burden is on the movant for recusal to show that the judge has a "high level of antagonism" so deep-seated that it would be impossible for the judge to render fair judgment. ${ }^{113}$ The norm that emerged is that need for recusal exists only when a judge displays an attitude or a state of mind that is so closed to fairness that the reasonable person would question the judges' impartiality. ${ }^{114}$ Just as Republican Party $v$. White extends First Amendment protection

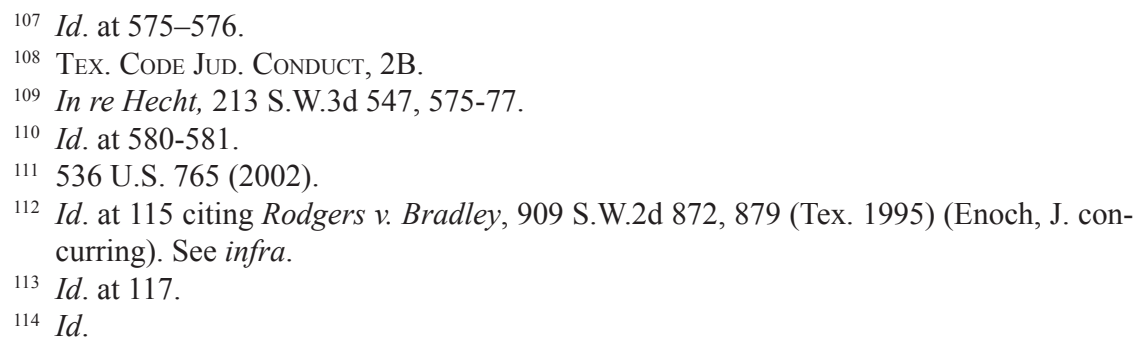


to judges' political statements, so too does it protect opinions expressed by persons before becoming judges. ${ }^{115}$

Under constitutional disqualification provisions, a judge is disqualified if he or she has a pecuniary interest in a case. The question is whether campaign contributions constitutive a pecuniary interest. A reasonable member of the public might expect a judge to recuse or even be disqualified if an attorney arguing before the judge contributed money to the judge's political campaign. But that expectation does not square with existing case law. In Rocha v. Ahmad, ${ }^{116}$ two justices on the Court of Appeals (San Antonio) were reported to have received thousands of dollars in campaign contributions from a prominent San Antonio attorney named Pat Maloney about whom a local newspaper made repeated references to his political influence. As a result, a motion was filed to recuse the two justices who received the contributions from one of the litigants represented by Maloney. The Court of Appeals rejected the motion, finding nothing in Canon 2 that applied. The only provision (Canon 3B (2)) that was applicable requires a judge to be "remain unswayed by partisan interests, public clamor, or fear of criticism." Chief Justice Cadena of the Court of Appeals pointed out that in an elected system, judges must "unfortunately" seek contributions. ${ }^{117}$ When judicial races are competitive, and voter apathy high, attorneys are the principal source of contributions in judicial elections. Of course Rocha was decided in the 1980s, which was a decade of relative sanity before the emergence of million dollar judicial campaigns waged by corporations and Political Actions Committees (PACs) in the 1990s. If a judge cannot sit on a case in which a contributing lawyer is involved as counsel, then judges would have to recuse themselves in a majority of cases in their courts. ${ }^{118}$ In Aguilar $v$. Anderson, ${ }^{119}$ a motion for recusal was filed against the presiding judge because the judge solicited and accepted a campaign contribution from an attorney representing a party to a suit. The Court of Appeals upheld the decision denying recusal, reiterating what had become axiomatic: a dilemma would be created if judges could not sit in cases involving attorneys who have contributed to a judge's campaign. The court argued that the standard must be whether "a reasonable person on the street-not the judge, the litigant or his attorney-would question the judge's impartiality ..." "[I]n states that elect judges the 'reasonable' person must know that judges have to stand for election on a regular basis, that elections cost money ... and that in judicial races most contributions are made by practicing

\footnotetext{
${ }^{115} I d$. at 119 .

116 Rocha v. Ahmad, 662 S.W.2d 77 (Tex. App.-San Antonio 1983),

117 Id. at $78-79$.

${ }_{118}$ Id.

119855 S.W.2d 799, 804-05 (Tex. App. - El Paso 1993).
} 
attorneys." ${ }^{120}$ Further, in Degarmo v. State, ${ }^{121}$ the Court of Appeals rejected as the sole grounds for recusal a campaign contribution of $\$ 500$ to a trial judge from the parents of a murder victim. In a recusal hearing, the judge admitted that he accepted the campaign contributions (in a first election, he did not win) from the parents of the murder victim's father but never promised or represented to the victim's family how he might act should he preside in the case. In his second (successful) campaign, he did not receive addition contributions from the victim's family. The Court of Appeals ruled that campaign contributions could not serve as independent grounds for recusal. ${ }^{122}$

By the early 1990s, judicial candidates felt increasing pressure to make campaign promises, run negative ads about their opponents, and spend a disproportionate amount of their time and energy raising money. ${ }^{123}$ PACs began to exert power in judicial campaigns. In Rogers, et al. v. Bradley, ${ }^{124}$ the Texas Supreme Court heard a motion to recuse filed by a patient, Rogers, suffering from complications from a liposuction procedure. Rogers and other injured plaintiffs won a $\$ 9$ million jury award in malpractice suit filed against Dr. Brian Bradley, who performed the procedure. The Court of Appeals reversed the trial court's judgment and the appellants filed a writ of error in the Supreme Court to reverse the Court of Appeals. The appellants also filed a motion to recuse several justices on the Texas Supreme Court including Justices Hightower, Hecht, Cornyn, and Enoch because of a 19-minute video. ${ }^{125}$ The origins of the video can be traced back to 1992 when TEX-PAC, supported by the Texas Medical Association, began a concerted effort to counter the influence of trial lawyers on the Texas Supreme Court. TEX-PAC produced "Court Wars III," a parody of Star Wars. In the video, Texas trial lawyers were analogized with Darth Vader's evil empire, bringing endless unwarranted medical malpractice suits against honest and caring doctors. The TEX-PAC video supported incumbent Justice Jack Hightower, Fifth Court of Appeals Chief Justice Craig T. Enoch's challenge to incumbent Justice Oscar Mauzy, and incumbent Justice Eugene A. Cook's reelection campaign against $131^{\text {st }}$ District Court Judge Rose Spector. Clips featuring all five of the named favorite candidates appeared in the video. None of the candidates were filmed expressly for the video or authorized

${ }^{120}$ Id. On the matter of the test for impartiality, see Rosas v. State, 76 S.W.3d 771 (Tex. App.-Houston ( $1^{\text {st }}$ Dist.) 2002): "Recusal is appropriate if the movant has provided enough facts to establish that a reasonable person, knowing all the circumstances involved, would harbor doubts as to the impartiality of the judge."

121922 S.W.2d 256 (1996).

${ }^{122} I d$. at 267-68.

${ }^{123}$ For data on campaign spending, see the Texas Ethics Commission web site, http:// www.ethics.state.tx.us/guides/JCOH_guide.htm; Texans for Public Justice, http:// www.tpj.org; and Frontline: Reform Efforts in Texas and Other States, http://www.pbs. org/wgbh/pages/frontline/shows/justice/howshould/.

124909 S.W.2d 872 (1995).

${ }^{125}$ Id. at 873. 
TEX-PAC to use their image or words from the various events for the campaign spot. The video also contained brief comments by two incumbents not on the ballot in 1992, Justices Cornyn and Hecht. Dr. Bradley, who was appealing the $\$ 9$ million medical malpractice verdict, appeared in the video and made an emotional plea for a "fair" court. The campaign video was not merely a plea to voters to support of particular judicial candidate whom TEX-PAC deems friendly to the medical profession but an elaborate and not so thinly veiled plea to sitting justices and judicial candidates to consider Dr. Bradley's unfair jury verdict. While the video spoke of fair and independent justices, the obvious point was that particular justices were allies to the medical profession and that Dr. Bradley's fate was inextricably tied to the presence of particular justices on the court whom TEX-PAC supports. ${ }^{126}$

Responding to the motion for recusal brought by Rogers, Texas Supreme Court Justice Bob Gammage ${ }^{127}$ argued for the recusal of all justices, including himself, based on the fact that the video made a direct and express association between support for certain candidates and the probable result in a pending case. At that time, recusal law stated that "...a judge shall recuse himself in any proceeding in which his impartiality might reasonably be questioned." 128 Justice Gammage argued that recusal law-which was silent on the matter of campaign ads run by a third party-should be understood as follows: A judge should recuse from participation in a pending or impending case under Rule $18 \mathrm{~b}(2)$ (a) if a person or entity has sought to engender support, financial or otherwise, for a judicial candidate or group of candidates that would preside in that case and this effort is made through a medium which is intended to be widely circulated and where that effort ties the success of the person's or entity's chosen candidates to the probable result of that case. The recusal law applies not only to judges who have engaged in obvious biased or prejudicial conduct but also to judges whose "impartiality might reasonably be questioned" regardless of the circumstances giving rise to the question of impartiality even though the circumstances "may be beyond the judge's volition or control." 129

Justice Craig Enoch responded that he saw no basis for Gammage's or any other justice's recusal and he took issue with Gammage's "declaration," as Enoch called it. If Gammage's reasoning were followed, all nine of the current justices would need to recuse solely on the basis of the political speech of a third party, he argued. Recusal would then be required even

${ }^{126} \mathrm{Id}$. at $874-875$.

127 Robert A. "Bob" Gammage served as a justice on Third Court of Appeals from 1982 to 1990 and on the Texas Supreme Court from 1990 to 1995. Along with other advocates of judicial reform, including Chief Justice Thomas R. Phillips, Gammage pushed for the adoption of an appointive method of judicial selection. As a justice, he had a solid record of support for civil rights and liberties. See John C. Domino, The Jurisprudence of Texas Supreme Court Justice Robert A. "Bob" Gammage: A Legacy of Civil Rights \& Liberties. 55 S. Tex. L. Rev. 27 (2013).

128 Tex. R. App. P. 15a, Tex. R. Civ. P. $18 b$.

${ }_{129}$ Rogers, 909 S.W.2d at 874. 
where there is no questionable conduct on the part of the judge but solely because of a political action committee's endorsement of or opposition to sitting justices on the Court. Gammage reasoned that TEX-PAC was not merely engaged in political speech but it was attempting to use the ongoing case as part of its strategy to elect certain kinds of judges, including the ones currently serving on the Court. However, Enoch argued that nothing in state or federal law required recusal of any justice in this case ${ }^{130}$ and inferred that Gammage was attempting to rewrite recusal law. In the end, the full court rejected the motion to recuse, ${ }^{131}$ with the exception of Justice Gammage who used the opportunity to set forth a broad recusal philosophy. For him, these kinds of campaigns constituted another form attack on the independence of the judicial branch. Many factors weaken independence, ranging from judicial candidates promising a particular kind of outcome in civil or criminal cases, to large expensive campaigns that send the message to judges that they cannot win office without the support of a powerful group or cartel of professional interests, to third party attack ads of the "Court Wars" variety that erode confidence in the judiciary by either driving home the point that justice is for sale or motivating the wealthy voter to join in and try to buy justice. Justice Gammage argued that judges in certain circumstances should recuse themselves because of the actions of third parties, especially when there were no laws or rules addressing the role of PACs in judicial elections. The year that Rogers $v$. Bradley was decided Gammage retired from the Texas Supreme Court in protest over the million dollar campaigns that began to emerge in the 1990s. ${ }^{132}$

In Rogers, Justice Enoch went on record that while he personally deplored the system under which Texas judges are selected, ${ }^{133}$ no justice should be expected to recuse because TEX-PAC or any other PAC seeks to

${ }^{130}$ See Tex R. App.P. 15a (incorporating by reference Rule 18b, which states "A judge shall recuse himself in any proceeding in which ... his impartiality might reasonably be questioned..." Tex R. CIV. P 18b (2) (a)).

${ }^{131}$ When a party files a motion to recuse a justice on the Texas Supreme Court, he or she must either recuse from participation in the case or certify the question to the rest of the court sitting en banc, which then decides the disqualification question by majority vote. Tex. R. App. P. 16.3. If a justice is disqualified, the chief justice will certify to the governor who can appoint a replacement justice. Tex. Gov't Code Ann. Sec. 22.005. http://www.statutes.legis.state.tx.us/Docs/GV/htm/GV.22.htm.

132 In 1999, former Justice Gammage was interviewed by Bill Moyers on a national PBS Frontline program called "Justice for Sale," http://www.pbs.org/wgbh/pages/frontline/ shows/justice/. Gammage said; "As a candidate, I spent a disproportionate amount off my time on the telephone making calls, going to fund-raising events ... The more money you have, the more you're permitted to run positive. The less money you have, the more you have to go on the negative. My ads were almost totally negative. I don't like to do that, but I had no choice [in order to be re-elected]. I had to penetrate the media markets."

${ }^{133}$ See Craig Enoch, 1995 Annual Survey of Texas Law: Foreword, 48 S.M.U. L. Rev. 723 (1995). 
raise campaign funds to support or contest the election of justices. Justice Gammage's reasoning would "totally disrupt the efficient administration of justice in Texas" because under his reasoning, only justices who faced no election opposition would be able to carry out their responsibilities without regularly recusing themselves. If the written or electronic statements of a PAC — or clips of justices' speeches used by a PAC—are grounds for recusal because they compromise the perceived impartiality of justices, then few judges would remain on the bench. Enoch concluded that the problem was with the method by which Texas selects judges and called on the legislature to reform the system. ${ }^{134}$

Justice Gammage's recusal philosophy in Rogers $v$. Bradley, which focuses not only on the judge but on those with a disproportionate influence on the outcome on judicial elections, foreshadowed the US Supreme Court's ruling Caperton v. A.T. Massey Coal Co. ${ }^{135}$ In this case, the Court found that while, traditionally, matters of judicial recusal and disqualification are settled by statutes and codes of conduct and do not normally pose a constitutional question, the millions of dollars in campaign contributions spent by Massey Coal to elect a state supreme court justice supportive of their cause violated the US Constitution's due process guarantee of a fair tribunal. ${ }^{136}$

As in the Texas case Rogers v. Bradley, the question in Caperton was whether the action of a third party-Blankenship and his PAC-rather than the actions of a judge demands recusal. The Court answered in the affirmative and reversed the ruling of the Supreme Court of Appeal of West Virginia. Caperton, similar to Rogers $v$. Bradley, raises an issue not addressed in past precedents or codes of conduct: does the behavior of a wealthy campaign contributor who is instrumental in electing a judge presiding in a case that will benefit said contributor create a constitutionally intolerable probability of actual bias of the judge? ${ }^{137}$ The inquiry in Caperton was not into Justice Benjamin's "subjective assessment” of his own impartialitywhether he perceived himself to be biased. No one knows what was in Justice Benjamin's mind. There was no evidence of a bribe or statements that indicate bias. He believed that he could remain impartial. However, Justice Kennedy reasoned that the guarantee of due process does not require proof of actual bias but that given an objective "appraisal of psychological tendencies and human weakness," there is a risk of actual bias or prejudgment. Not every campaign contribution by a litigant or an attorney creates a probability of bias that requires recusal but that "objective and reasonable perceptions" show that there is a risk of bias "when a person with a personal stake in a particular case had a significant and disproportionate influence in placing the judge on the case by raising funds or directing the

\footnotetext{
134909 S.W. 2d 872; 1995 Tex. LEXIS 133.

135556 U.S. 868 (2009).

136 Id. at 876 citing FTC v. Cement Inst., 333 U.S. 683, 702 (1948).

137 Ungar v. Sarafite, 376 U.S. 575 (1964).
} 
judge's election campaign when the case was pending or imminent." ${ }^{138}$ Texas law currently maintains that a judge is neither disqualified nor subject to recusal because of campaign contributions. Caperton is not understood as stating that every campaign contribution by a litigant or an attorney necessitates recusal unless circumstances produce a violation of due process or an unconstitutional probability of bias amounting to the denial of due process. In sum, campaign contributions cannot serve as independent grounds for recusal. ${ }^{139}$

\section{The Aftermath of Caperton in Texas}

Post-Caperton, the Texas Supreme Court Advisory Committee (SCAC) proposed reforms to recusal standards under Rules $18 \mathrm{a}$ and $18 \mathrm{~b}$ of the Texas Rules of Appellate Procedure. ${ }^{140}$ Minor changes were made by the Court but nothing substantive that directly addresses the issues raised in Caperton was adopted. Nor has the Texas Supreme Court either cited or discussed Caperton $^{141}$ in any published opinion. Caperton has been cited in appeals from adverse recusal motions heard by the Court of Criminal Appeals in Gaal v. State in $2011^{142}$ and four Texas Court of Appeals decisions: Villareal v. State in 2011, ${ }^{143}$ Black v. 7-Eleven Convenience Stores in 2014, ${ }^{144}$ McIntosh v. Texas State Bd. of Dental Examiners in 2014, ${ }^{145}$ and Barfield v. Texas in 2015. ${ }^{146}$ In Gaal, the Court of Criminal Appeals reversed the decision of the Court of Appeals that denied a motion to recuse a judge in a driving while intoxicated case. Gaal simply reiterated the existing grounds for recusal in Texas, but in a single footnote cited Caperton as setting out three situations that violate the Due Process Clause of the Fifth Amendment: First, when a judge has a financial interest in the case. Second, when

138 Caperton, 556 U.S. at 884.

139 Rocha v. Ahmad, 662 S.W.2d 77 (Tex. App.--San Antonio 1983); Delgarmo v. State 922 S.W.2d 256 (Tex. App.-Houston (14 ${ }^{\text {th }}$ District) 1996); River Road Neighborhood Association v. South Texas Sports, Inc., 673 S.W. 2d 952, 953 (Tex. App.-San Antonio 1984); Manges v. Guerra, 673 S.W.2d 180 (Tex. 1984).

140 Texas Supreme Court Advisory Comm., Meeting of the Texas Supreme Court Advisory Comm. 20301, 20314-15, 20320, 20391 (2010), available at http://www.supreme. courts.state.tx.us/rules/scac/2010/091710-trans.pdf._See also Seana Willing, Post-Caperton Recusal Reform in Texas. Is it Needed?,51 S. Tex. L. Rev. 1143 (2010).

141 (Westlaw and LexisNexis searches, 2015).

142332 S.W.3d 448 (2011).

143348 S.W.3d 365 (2011).

144 No. 03-12-00014-CV, 2014 Tex. App. LEXIS 2641.

145 No. 07-12-00196-CV, 2014 WL 931260.

146 No. 14-13-00518-CR, 2015 WL 1544790. 
the judge acted as a "one-man grand jury" to bring charges in the case he or she is trying. Third, "when a person with a personal stake in a particular case had a significant and disproportionate influence in placing the judge on the case by raising funds or directing the judge's election campaign when the case was pending or imminent." ${ }^{147}$ Similarly, in each of the four Court of Appeals cases above, appellants raised due process concerns under Caperton along with the recognized grounds for recusal. In Black, ${ }^{148}$ the court ruled that the trial judge did not abuse his discretion by denying Black's recusal motion because it was not established that the judge's alleged biases arose from an extrajudicial source or that Black was denied due process under the Caperton standard. ${ }^{149}$ In Villareal, ${ }^{150}$ the court rejected a recusal motion alleging the trial judge harbored a prejudice against the defendant contrary to a ground for recusal established by Caperton: that the "probability of actual bias on the part of the judge... is too high to be constitutionally tolerable." ${ }^{151}$ McIntosh held that a judge's mere disagreement of party's legal position did not demonstrate a bias or prejudice amounting to a violation of due process and requiring recusal. ${ }^{152}$ In Barfield, the court ruled that displaying a Mother's Against Drunk Driving (MADD) plaque in the courtroom did not violate the Code of Judicial Conduct, thus casting doubt on the impartiality of the judge amounting to a denial of due process under Caperton. ${ }^{153}$

As the above account indicates, Texas disqualification and recusal jurisprudence is conservative and restrained. It continues to be based on a narrow judicial interpretation of state constitutional provisions, statutes, and codes of conduct that are intended to promote impartiality and accountability without creating a net loss to judicial discretion and the stability of the judicial process. At minimum, it ensures that the actions of the judge should not give rise to reasonable grounds to question the neutral and objective character of a judge's rulings or findings. Whether this conservatism and restraint can continue unchanged in a post-Caperton era remains to be seen. The Caperton probability of bias standard has become part of the dialogue on recusal and disqualification in Texas; however, the actual impact of Caperton in the state has been limited by several factors. The fact that recent motions for recusal based on Caperton were viewed skeptically and ultimately denied with little or no discussion by appellate courts suggests continued resistance to judicially driven changes in the state's recusal jurisprudence. A presumption exists that the state's code of judicial conduct offers more protection against judicial bias than the Caperton standard

\footnotetext{
147332 S.W.3d 448, 453 n. 10 (2011).

148 No. 03-12-00014-CV; 2014 Tex. App. LEXIS 2641.

149 Id. at 15.

150348 S.W.3d 365 (2011).

${ }^{151} \mathrm{Id}$. at $372,373$.

152 No. 07-12-00196-CV, 2014 WL 931260.

153 No. 14-13-00518-CR, 2015 WL 1544790.
} 
requires. This would explain the reluctance of Texas Supreme Court to use its rule-making authority to rewrite recusal guidelines. In addition, in a state that elects its judges, state recusal precedent still adheres to the position that campaign contributions alone do not create grounds for recusal nor necessarily are the actions of a powerful PAC or contributor automatic grounds for disqualification of a judge presiding in that case unless the circumstances created by the campaign contributions give rise to an unconstitutional probability of bias. Texas' Judicial Campaign Fairness Act of $1995^{154}$ thus tempers the impact of Caperton because it imposes a strict $\$ 300,000$ ceiling as the maximum donation from a political action committee to a candidate for statewide judicial office. This is the highest contribution permitted from any category of donor in Texas-well below the $\$ 3$ million spent by Don Blankenship and his PAC to elect Brent Benjamin to the West Virginia Court of Appeals in the Caperton case.

Caperton challenges are unlikely to prevail in the near future because many members of the bench and bar share the belief that the state's judicial campaign contribution restrictions and recusal jurisprudence create a firewall against violations of the Due Process Clause. However, continued resistance to change may further erode confidence in existing ethical safeguards. Texans hold a deep-seated lack of confidence in the fairness of the judicial system since the days of "Court Wars" and the million-dollar judicial elections in the early 1990s. Concerns that wealthy donors continue to exercise disproportionate influence on the judiciary have not yet been assuaged.

${ }^{154}$ TEX. ELEC. CODE ANN. Section 253.15 (Vernon Supp. 2002). Specific limits are found on the Texas Ethics Commission's Campaign Finance Guide for Judicial Candidates and Officeholders, https://www.ethics.state.tx.us/guides/JCOH_guide.htm. 
